\section{Plant Population Influence on Squash Yield, Sweetpotato Whitefly, Squash Silverleaf, and Zucchini Yellow Mosaic}

\author{
Charles A. Powell, Peter J. Stoffella, and Harry S. Paris ${ }^{1}$ \\ Agricultural Research and Education Center, Institute of Food and Agricultural \\ Sciences, University of Florida, Box 248, Fort Pierce, FL 34954
}

Additional index words. Cucurbita pepo, Bemisia tabaci

Abstract. Zucchini squash (Cucurbita pepo L.) fruit yield and the incidence of sweetpotato whitefly (SPWF) [Bemisia tabaci (Gennadius)], squash silver leaf (SSL) disorder, and zucchini yellow mosaic virus (ZYMV) were measured during Spring and Fall 1991 in experiments containing various plant populations. In both experiments, as the within-row spacing increased from 30.5 to $76.2 \mathrm{~cm}$ or the number of plants per hill decreased from three to one, the number of marketable fruit per hectare decreased, and the marketable fruit per plant increased. Adult SPWF populations increased with decreased within-row spacing in the spring but not the fall experiment. The incidence of SSL or ZYMV infection was not affected by plant population in either experiment. The results indicate that increasing zucchini squash plant population can increase yield without affecting the incidence of SSL or ZYMV.

A basic concern during crop production is determining the optimum plant population for maximum yield and fruit quality (Bleasdale, 1966). In cucurbit crops grown in hills, three criteria determine plant population: withinrow spacing, plant number per hill, and distance between rows. Differences in these criteria may influence yields and fruit quality independently or through interaction with other cultural and management practices.

Plant population can affect fruit yield directly or indirectly through influencing insects or diseases. One insect that frequently affects yield in zucchini squash is the sweetpotato whitefly (SPWF). This insect's feeding is associated with the squash silver leaf (SSL) disorder (Schuster et al., 1991; Yokomi et al., 1990), which has caused significant economic losses in Florida (Simons et al., 1988). This disorder is characterized by silver coloration along the veins of younger leaves. The silvering becomes more intense as the leaves mature, until the entire upper (adaxial) surface of the leaf is silver. In severe outbreaks, fruit can also become lighter green or pale.

Zucchini yellow mosaic disease results in severe symptoms on zucchini squash leaves and fruit (Provvidenti et al., 1984; Purcifull et al., 1984) and is caused by zucchini yellow mosaic virus (ZYMV) (Lisa et al., 1981). This disease is characterized by severe mosaic and

Receivedforpublication28July 1992. Accepted for publication 8 Feb. 1993. Florida Agricultural Experiment Station journal series no. R-02543. We thank Mike Fleming and Jack Cordy for technical assistance. The cost of publishing this paper was defrayed in part by the payment of page charges. Under postal regulations, this paper therefore must be hereby marked advertisement solely to indicate this fact.

'On sabbatical leave from the Dept. of Vegetable Crops, Agricultural Research Organization, Newe Ya'ar Experiment Station, P.O. Haifa, Israel. distortion of younger leaves and diagnostic bumps and distortion of the fruit. This virus' vector is an aphid, and its incidence should not be related directly to whiteflies. The purpose of this investigation was to evaluate the influence of plant populations and planting arrangement on silverleaf, mosaic virus, whitefly, and fruit yield and quality of zucchini squash.

Experiments were conducted at the Agricultural Research and Education Center, Fort Pierce, Fla., during Spring and Fall 1991. The soil type was an Oldsmar fine sand (sandy, siliceous, hyperthermic Alfic Arenic Haplaquods). Raised beds $1.1 \mathrm{~m}$ wide and 0.15 $\mathrm{m}$ high were spaced $2.1 \mathrm{~m}$ apart, center to center. Fertilizer (in $\mathrm{kg} \cdot \mathrm{ha}^{-1}$ ) at $30 \mathrm{~N}-54 \mathrm{P}-25 \mathrm{~K}$ was incorporated into the beds. Additional fertilizer (in $\mathrm{kg} \cdot \mathrm{ha}^{-1}$ ) at $115 \mathrm{~N}-75 \mathrm{P}-227 \mathrm{~K}$ was applied to the bed surface in two bands, each $60 \mathrm{~cm}$ from the bed center. Beds were then covered with black (spring) or white (fall) polyethylene mulch. Subsurface irrigation was used throughout the season in both experiments to maintain the water table at $\approx 8 \mathrm{~cm}$ below the soil surface.

All plots received weekly applications of a polymer of manganous ethylene-bis-dithiocarbamate with zinc (mancozeb) at 1.78 $\mathrm{kg} \cdot \mathrm{ha}^{-1}$ and tribasic copper at $4.95 \mathrm{~kg} \cdot \mathrm{a}^{-1}$ for fungal disease control and 6,7,8,9,10,10hexachloro-1,5,5a,6,9,9a-hexahydro-6,9methano-2,4,3-benzodioxathiepin -oxide (endosulfan) at 2.34 liters $\cdot$ ha $^{-1}$ for insect control. Weeds were controlled between beds using 1,1'-dimethyl-4,4'-bipyridinium salts (paraquat) at 2.30 liters'ha' ${ }^{-1}$

'Senator' zucchini squash was seeded on 4 Mar. and 3 Sept. 1991 for the spring and fall experiments, respectively. Hills containing five seeds were placed in a single row per bed, $30.5,45.7,61.0$, or $76.2 \mathrm{~cm}$ apart. On emergence, each hill was thinned to one, two, or three plants at each within-row spacing. Each plot of the 12 within-row spacing/plants per hill treatment combinations consisted of 12 hills. Populations ranged from 6151 to 46,131 plants/ha (Table 1). The normal recommended population range for squash in Florida is 13,455 to 35,879 plants/ha (Olson and Sherman, 1985).

Squash was harvested from the center eight hills of each plot every Monday, Wednesday, and Friday for a total of 16 harvests, starting on 17 Apr., for the spring experiment and a total of 21 harvests, starting on 8 Oct., for the fall experiment. During each harvest, marketable fruits $15.2 \mathrm{~cm}$ or longer from each plot were counted and weighed. Severity of silvering was evaluated in the fall experiment on 1 Oct. and 15 Nov. by randomly choosing three plants in each plot and rating the most silvered leaf of each plant according to the 0-5 scale of Paris et al. (1987). Each plant in each plot was observed and counted weekly for symptoms of the leaf and fruit distortion that are diagnostic for ZYMV. ZYMV infection was confirmed serologically by selecting young leaves from 10 representative symptomatic and nonsymptomatic plants and analyzing them by enzyme-linked immunosorbent assay. Fruit showing characteristic ZYMV malformations were counted and weighed and were considered unmarketable. Adult SPWF populations were monitored weekly using $3 \times 3-\mathrm{cm}$ yellow sticky boards (Great Lakes IPM, Vestaburg, Mich.) that were placed $38 \mathrm{~cm}$ above the center of each plot and replaced every 7 days (Powell and Stoffella, 1990).

A randomized complete block design with treatments replicated four times was used for each experiment. Each measured and calculated variable was subjected to an analysis of. variance (ANOVA). Main effects were partitioned into linear or quadratic responses. Mean adult whitefly catches also were subjected to linear regression analysis for each main effect treatment (plants per hill and within-row spacing). Adult whitefly population means were subjected to a square-root transformation before ANOVA or regression analyses. Regression slopes $\left(b_{1}\right)$ between main effect treatments were subjected to a $t$ test, $P=0.05$, for each experiment.

The yield of marketable squash fruit per hectare increased linearly as the within-row spacing decreased in both experiments (Table 2 ). In the spring experiment, fruit weight per

Table1.Squashplantpopulations at various withinrow spacings and plants per bill.

\begin{tabular}{lcc}
\hline $\begin{array}{l}\text { Within-row } \\
\text { spacing } \\
\text { (cm) }\end{array}$ & $\begin{array}{c}\text { Plants/ } \\
\text { hill } \\
\text { (no.) }\end{array}$ & $\begin{array}{c}\text { Plant } \\
\text { population } \\
\text { (plants/ha) }\end{array}$ \\
\hline 30.5 & 1 & 15,377 \\
& 2 & 30,754 \\
45.7 & 3 & 46,131 \\
& 1 & 10,251 \\
61.0 & 2 & 20,502 \\
& 3 & 30,754 \\
76.2 & 1 & 30,754 \\
& 2 & 15,377 \\
& 3 & 23,066 \\
& 2 & 6,151 \\
& 3 & 12,302 \\
& & 18,452 \\
\hline
\end{tabular}




\begin{tabular}{|c|c|c|c|c|c|c|c|c|c|c|}
\hline \multirow[b]{3}{*}{$\begin{array}{l}\text { Main } \\
\text { effects }\end{array}$} & \multicolumn{10}{|c|}{ Marketable fruit } \\
\hline & \multicolumn{5}{|c|}{ Spring } & \multicolumn{5}{|c|}{ Fall } \\
\hline & t.hat $a^{-1}$ & $\begin{array}{l}\text { Fruit/ha } \\
(1000 \mathrm{~s})\end{array}$ & $\begin{array}{c}\mathrm{kg} / \\
\text { plant }\end{array}$ & $\begin{array}{c}\text { no./ } \\
\text { plant }\end{array}$ & $\mathrm{g} /$ fruit & t.ha $a^{-1}$ & $\begin{array}{l}\text { Fruit/ha } \\
(1000 \mathrm{~s})\end{array}$ & $\begin{array}{l}\mathrm{kg} / \\
\text { plant }\end{array}$ & $\begin{array}{c}\text { no./ } \\
\text { plant }\end{array}$ & $\mathrm{g} /$ fruit \\
\hline \multicolumn{11}{|c|}{$\begin{array}{l}\text { Within-row spacing } \\
\text { (WRS) (cm) }\end{array}$} \\
\hline 30.5 & 47.1 & 181 & 4.1 & 7.0 & 261 & 32.6 & 138 & 2.9 & 5.4 & 236 \\
\hline 45.7 & 41.9 & 154 & 5.3 & 8.6 & 273 & 31.9 & 130 & 4.1 & 7.5 & 242 \\
\hline 61.0 & 38.0 & 134 & 6.4 & 10.1 & 281 & 29.1 & 121 & 4.8 & 9.0 & 245 \\
\hline 76.2 & 36.4 & 123 & 7.4 & 11.2 & 297 & 29.1 & 117 & 6.3 & 11.1 & 251 \\
\hline Significance ${ }^{z}$ & $\mathrm{~L}^{* *}$ & $\mathrm{~L}^{* *}$ & $\mathrm{~L}^{* *}$ & $\mathrm{~L}^{* *}$ & $\mathrm{~L}^{* *}$ & NS & $\mathrm{L}^{* *}$ & $\mathrm{~L}^{* *}$ & $\mathbf{L}^{* *}$ & NS \\
\hline \multicolumn{11}{|l|}{$\begin{array}{l}\text { Plants/hill } \\
\text { (PH) (no.) }\end{array}$} \\
\hline 1 & 36.6 & 123 & 8.7 & 13.1 & 298 & 28.7 & 111 & 7.1 & 12.2 & 261 \\
\hline 2 & 42.7 & 157 & 5.2 & 8.6 & 273 & 30.7 & 130 & 3.8 & 7.2 & 236 \\
\hline 3 & 43.3 & 164 & 3.6 & 6.0 & 264 & 32.6 & 139 & 2.7 & 5.2 & 233 \\
\hline Significance & $\mathrm{L}^{*}$ & $\mathrm{~L}^{* *}$ & $Q^{*}$ & $\mathrm{Q}^{*}$ & $\mathbf{L}^{* *}$ & NS & $\mathbf{L}^{* *}$ & $\mathrm{Q}^{* *}$ & $\mathrm{Q}^{* *}$ & $\mathrm{~L}^{* *}$ \\
\hline $\mathrm{WRS} \times \mathrm{PH}^{\mathrm{z}}$ & NS & NS & NS & NS & NS & NS & NS & $*$ & $*$ & NS \\
\hline
\end{tabular}

z

Ns, *** Nonsignificant or significant at $P \leq 0.05$ or 0.01 , respectively.

hectare also increased linearly as the withinrow spacing decreased. The number and weight of fruit per plant increased linearly as withinrow spacing' increased in each experiment. In the spring experiment, fruit weight (grams per fruit) also increased with increased distance between hills.

A similar effect occurred when plant population was varied by the number of plants per hill (Table 2). The marketable fruit per hectare increased linearly with increasing plants per hill in each experiment. Weight of marketable fruit per hectare increased with increasing plants per hill in the spring experiment. Increasing plants per hill decreased the number and weight of fruit per plant quadratically and decreased fruit weight (grams per fruit) linearly in each experiment. A significant withinrow spacing $\times$ plant per hill interaction occurred for marketable fruit per plant in the fall experiment (Table 2).

Increasing squash plant population, by decreasing within-row spacing to $30.5 \mathrm{~cm}$ and increasing plants per hill to three, increased marketable fruit count (Table 2). The decrease in weight and number of fruit per plant with increased plant populations was more than offset by the greater number of plants producing fruit.

Increasing squash plant populations might be expected to increase the incidence of diseases and pests. However, in the fall experiment, when SPWF were prevalent, mean adult whitefly catches, whitefly population growth, and silverleaf ratings (Table 3 ) were not significantly different between within-row spacing or plant per hill treatments. In the spring experiment, decreased within-row spacing increased adult whitefly trap catch (Table 3), but no silverleaf symptoms occurred, possibly because the number of whiteflies in spring was much lower than in fall. Also, there was no difference in the percentage of plants or fruit with ZYMV symptoms among the treatments in either experiment (mean of $11 \%$ symptomatic plants in both experiments). No other disease or insect problem occurred in any of the squash plots.

Studies with zucchini have shown that populations exceeding 30,000 plants/ha give

Table 3. Plant population effects on sweetpotato whitefly (SPWF) population and silver leaf symptoms on summer squash, 1991.

\begin{tabular}{|c|c|c|c|c|c|c|}
\hline \multirow{3}{*}{$\begin{array}{l}\text { Main } \\
\text { effects }\end{array}$} & \multicolumn{2}{|c|}{ Mean adult SPWF } & \multicolumn{4}{|c|}{ Fall 1991} \\
\hline & Spring & Fall & Regression mo & & Leaf si & g rating \\
\hline & \multicolumn{2}{|c|}{ No./week } & Equation & $R^{2}$ & 1 Oct. & 15 Nov \\
\hline \multicolumn{7}{|c|}{$\begin{array}{l}\text { Within-row spacing } \\
\text { (WRS) (cm) }\end{array}$} \\
\hline 30.5 & 3.2 & 40.2 & $\mathrm{y}=1.20+0.13 \mathrm{x}_{1}$ & 0.70 & 1.2 & 3.8 \\
\hline 45.2 & 2.4 & 38.2 & $y=1.77+0.14 x_{1}$ & 0.68 & 1.5 & 3.8 \\
\hline 61.0 & 2.3 & 39.5 & $y=1.68+0.14 x_{1}$ & 0.69 & 1.6 & 4.0 \\
\hline 76.2 & 2.1 & 40.3 & $y=2.18+0.15 x_{1}$ & 0.73 & 1.6 & 4.2 \\
\hline Significance & $\mathrm{L}^{*}$ & NS & & & NS & NS \\
\hline \multicolumn{7}{|l|}{$\begin{array}{l}\text { Plants/hill } \\
\text { (PH) (no.) }\end{array}$} \\
\hline 1 & 2.6 & 40.7 & $\mathrm{y}=2.42+0.15 x_{1}$ & 0.72 & 1.4 & 4.1 \\
\hline 2 & 2.5 & 41.1 & $y=1.79+0.14 x$ & 0.72 & 1.4 & 3.8 \\
\hline 3 & 2.4 & 36.6 & $y=0.92+0.12 x_{1}$ & 0.68 & 1.5 & 4.0 \\
\hline Significance & NS & NS & & & NS & NS \\
\hline $\mathrm{WRS} \times \mathrm{PH}$ & NS & NS & & & NS & NS \\
\hline
\end{tabular}

${ }^{7}$ Adult SPWF numbers are based on weekly counts from yellow sticky boards.

${ }^{y}$ Regression model parameters are $y=$ adult SPWF numbers, $x_{1}=$ days after seeding; regression slopes $\left(b_{1}\right)$ between main effect treatments are not significantly different according to $t$ tests.

${ }^{x}$ Ratings are based on a 0 (no silvering) to 5 (complete silvering) scale.

ss. *Nonsignificant or significant at $P \leq 0.05$, respectively; $\mathrm{L}=$ linear. highest yields (Dweikat and Kostewicz, 1989; Paris et al., 1986). A doubling of marketable yield (weight) was obtained by increasing the population from 10,000 to 60,000 plants/ha in 'Goldy' (Paris et al., 1986), whereas a $40 \%$ yield increase (weight) was obtained by increasing the 'Senator' population from 11,000 to 56,000 plants/ha (Dweikat and Kostewicz, 1989). Our results showed a $68 \%$ increase in total fruit weight in the fall experiment for 'Senator' squash by increasing the population from 6000 to 46,000 plants/ha. Although earlier studies with zucchini and crookneck squash had shown more modest increases in yield by increasing plant density, Dweikat and Kostewicz (1989) have reported that optimal fertilization is required to exploit the potential for increasing yields by planting at higher densities.

Plant size and growth habit differences can profoundly affect crop response to plant density variation (Bleasdale, 1966). Differential response of zucchini cultivars to increased plant density has been attributed to differences in their plant size and growth habit (Paris et al., 1983). 'Senator' plants have an open growth habit and are relatively large. The newer cultivars, combining open growth habit with smaller plant size, would be expected to respond even more favorably to higher plant density.

Paris et al. ( 1986) reported that virus symptoms in squash fruit decreased only slightly with increased density. Our results, which showed no effect of plant density on ZYMV infection, SPWF, or SSL, further suggest that the increase in yield derived from increased density would not be offset by higher incidence or severity of the two most serious maladies of this crop, ZYMV and SSL.

\section{Literature Cited}

Bleasdale,J.K.A.1966.Plantgrowthandcropyield. Am. Applied Biol. 57:173-182.

Dweikat, I.M. and S.R. Kostewicz. 1989. Row arrangement, plant spacing, and nitrogen rate effects on zucchini squash yield. HortScience 24:86-88.

Lisa,V.,G.Boccardo,G.D’ Agostino,G.Dellavalle, 


\section{Production and Culture}

and M. d'Aquilio. 1981. Characterization of a potyvirus that causes zucchini yellow mosaic. Phytopathology 71:667-672.

Olson, S.M. and M. Sherman. 1985. Squash production in Florida. Institute of Food and Agricultural Sciences, Univ. of Florida, Florida Coop. Ext. Circ. 103.

Paris, H. S., Z. Karchi, H. Nerson, and Y. Burger. 1983. Yield and yield quality in precocious yellow zucchini cultivars. HortScience 18:724726.

Paris, H. S., H. Nerson, and Y. Burger. 1987. Leaf silvering of Cucurbita. Can. J. Plant Sci. 67:593598 .
Paris, H. S., H. Nerson, and Z. Karchi. 1986. Yield and quality of courgette as affected by plant density. J. Hort. Sci. 61:295-301.

Powell, C.A. and P.J. Stoffella. 1990. Endosulfan and silver reflective mulch effects on sweet potato whitefly populations and yields of zucchini squash and tomatoes. Proc. Fla. State Hort. Soc. 103:117-119.

Provvidenti, R., D. Gonsalves, and H.S. Humaydan. 1984. Occurrence of zucchini yellow mosaic virus in cucurbits from Connecticut, New York, Florida, and California. Plant Dis. 68:443-446. Purcifull, D.E., W.C. Adlerz, G.W. Simone, E. Hiebert, and S.R. Christie. 1984. Serological relationships and partial characterization of zucchini yellow mosaic virus isolated from squash in Florida. Plant Dis. 68:230-233.

Schuster, D.J., J.B. Kring, and J.F. Price. 1991 Association of the sweetpotato whitefly with a silverleaf disorder of squash. HortScience 26:155-156.

Simons, J.N., P.J. Stoffella, K.D. Shuler, and R.N. Raid. 1988. Silver-leaf of squash in south Florida. Proc. Fla. State Hort. Soc. 101:397-399.

Yokomi, R. K., K.A. Hoelmer, and L.S. Osborne. 1990. Relationships between the sweetpotato whitefly and the squash silverleaf disorder. Phytopathology 80:895-900. 